\title{
A research on the gap between after 90 s graduates' job expectancy and real work cognition in Hospitality Industry
}

\author{
Danhe Wang* \\ School of International Hospitality Management, Sanya University, Sanya, Hainan 572022, China \\ 838117296@qq.com \\ *Corresponding author
}

Keywords: Job Expectancy; Work Cognition; After 90s; Hospitality Industry

\begin{abstract}
With the after 90s grow up, go to school, graduate and start to work, they have already become the main force of employment in hospitality industry. In 2017, the turnover rate in hospitality industry stay in $20 \%-40 \%$ which negatively affect the service quality in a hotel and at the same time, more than $60 \%$ of after 90 s graduates who are majored in hospitality management changed their occupation within one year after they graduate Obviously, there is a gap between after 90s graduates' job expectancy and their work cognition. Therefore, we need to find out what is the hotel needs or hotel expectation about the graduates now, what is the situation of graduates now, the gap between the market expectation and the graduates situation. During the research, both deductive and inductive approach is used to analyze the data and information. We distribute two kinds of questionnaire in this research which are questionnaires used for the after 90s employees in hotels and questionnaires used for after 90s graduates in schools. It can help us to find the reasons which cause the gap exist between job expectancy and job cognition. Meanwhile, interviews are made with hotel managers to find out how after 90s graduates are expected to perform after they start to work. At last, we found lack of right cognition about hospitality industry is the main reasons which causing the gap among the graduates. Besides, because of the different character and personality of after 90s, hotels need to change their management method while dealing with the after 90s.
\end{abstract}

\section{Introduction}

Hospitality industry is the product of society and human civilization development. The hospitality industry in China experienced the difficult period before 1980s, the start stage in 1980s, the booming stage in 1990s and is still developing now. Hospitality industry has already developed into a huge domain in China throughout the 40 years.

According to the data of National Statistic Department, there are a total of 11,685 hotels in China with 3,783,200 rooms in 2016 and 12,327 star hotels with 3,372,000 rooms in 2015. And the average occupied rate of rooms was $54.73 \%$ and $54.19 \%$ respectively. This also indicates the fact that the hotel industry in China is still booming.

\section{Background and statement of problem}

With the after 90s grow up, go to school, graduate and start to work, they have already become the main force of employment in hospitality industry today. Meanwhile, a research shows that the turnover rate of hospitality industry reached to 40\% in March 2017 which makes it the top of the list. The actual situation in most of the hotels within China includes: lack of employees both at service and management level, the turnover rate stay in $20 \%-40 \%$ which negatively affect the service quality in a hotel. At the same time, more than $60 \%$ of after 90 s graduates who are majored in hospitality management changed their occupation within one year after they graduate. Obviously, there is a gap between after 90s graduates' job expectancy and the real work cognition.

After 90s has the different grow up background, sense of worth, employment view, life attitude and work attitude comparing with after 80s. Therefore, make a research about after 90s' graduates' job expectancy, their real work cognition and the gap between the two does make sense. First, it can 
help the after 90s graduate have a clear cognition of the real work in hospitality industry, benefit themselves to do the career planning. Second, it can help hotels to change their strategy or management style when they are doing the after 90s human resources which may positively reduce the turnover rate.

\section{Research objective}

As we mentioned above, the aim of this research is to help hospitality schools' graduates and hospitality market understand each other better. So in order to do this, we need to find out what is the hotel needs or hotel expectation about the graduates now, what is the situation of graduates now, the gap between the market expectation and the graduates situation. So the research objectives are summarized as follow:

\subsection{To find out what kind of graduates are needed in hospitality industry from the aspect of HR managers}

The advice and point of view of HR managers of different hotels are very important. Because their need can mostly represent the market need.

\subsection{To assess the expectation of after $90 \mathrm{~s}$ graduates now}

In order to have a general understanding about the after 90s graduates, in this research we will do a research mainly about their future job expectancy of different aspects such as the position level, the salary level, the accommodation request, the future plan and etc. The reason why we doing a research about this is because we could make changes of graduates to let them fit the market need better only after we have a general understanding about them.

\subsection{To do a job satisfaction research of the new employees who have just graduate from schools}

The research why we are doing a job satisfaction research about the new employees is because we to compare the job they have now and the ideal job graduates want to have when they were still in school. And the existing gap between the two situation make the employees disappointed are what we want to find out.

\section{Methodology}

\subsection{Research philosophy}

We will apply Interpretivism in this article while we doing the research. The reason why it is the main research philosophy is because hospitality is a special industry which revolves about people, and in this article, all the data and analysis are coming from the questionnaires we received from the employees, which concludes the comments we received is based on the personal judgments and comments. Therefore it cannot guarantee the conclusion to be completely objective and standard. So we say that interpretivism is the main philosophy be used in this article. Beside the interpretivism, we will also use positivism more or less in this article, because after we collect all the questionnaires, we need to analyze the data of each question and use percentage and data to explain the truth, so from this aspect, we have to be objective and scientific. Therefore, we will use both positivism and interpretivism in this article, interpretivism is the primary philosophy and positivism is the subsidiary philosophy.

\subsection{Research approach:}

In this article, we are going to use both deductive and inductive approach to analyze the data and information we get. Generally speaking, we will use deductive approach to conclude the quantitative data we get from the questionnaires and we will use the inductive approach to summarize the general meaning of interviews we did.

In addition, we cannot clearly divide these two approaches in different situation. For example, 
when we look at the data of questionnaires, we can induct some conclusions form the data directly and at the same time we can also deduct some new conclusions according to the data we inducted before. So in this situation, we will use testing theory and building theory at the same time.

\subsection{Strategy}

Strategy, as the way we used to collect data and go through the process is quite important to the article. In this article, we are going to apply mixed strategy, namely, questionnaires and face to face interview will be applied in this article as two strategy. Questionnaires will be used to get quantity data, the interviews will be used to get quality information.

\section{Data collection and data analysis}

\subsection{Data collection procedures}

Questionnaires and interviews are the two methods we will use in this dissertation for information collection. The sample in this article are two academy schools and three five hotels which are Sanya University, Hainan Tropical Ocean University, The Ritz-Carlton Hotel, The MGM Hotel and The Sheraton Hotel in Sanya, Hainan province, China.

\subsection{Questionnaires}

We are going o use two kinds of questionnaire in this research which are questionnaires used for the after 90s employees in hotels and questionnaires used for after 90s graduates in schools. As we mentioned before, the reason we chose these two groups as research target is because we try to find the gap of that the after 90s graduates job expectancy and job cognition. Then we can try to find the reasons which cause the gap and these gap are the point in which we want to improve.

Before we build the questionnaires, we had communications with HR managers three hotels, explaining to them about the purpose of this research. All the three hotels are interesting in this subject and are glad to get involved. In addition, we had discussion with them about what their opinions. Then we build the questionnaires according to the suggestion of HR managers and employees and the need of this research. The details of the questionnaires are as followed:

\subsubsection{Questionnaires for students:}

We distribute 200 questionnaires to two Academy schools which are Sanya University and Hainan Tropical Ocean University. Two week s later we got 87 questionnaires back from Sanya University and nearly one week later got 74 questionnaires back from Hainan Tropical Ocean University. So in total we had receive 161 questionnaires and in order to make the research more successful, the teachers of the university helped us by doing the questionnaires research via the communication.

In this questionnaire, it includes 6 questions. The first five questions can help us to have a general idea about the students' job expectancy and the request about the future job. The sixth question which is "what factors will make you be refused by the employees during the interviews" can give an answer about what is still need to be improved by the students.

\subsubsection{Questionnaires for employees}

The second questionnaires is used for the after 90s employees and they can help us to finish the research objective which is job satisfaction research. After we spoke with the HR managers, they indicated that the common problems of hotels are employees lack of motivations to work and the turnover rate is so high which results in low service quality complains, and that situation is worse among the new employees who are past 90s. So in the employees questionnaires, we build questions like "are you satisfied with your job", "which part of the job you do not like”, "do you think you have the motivation to work and why" etc. Beside this, because we try to find the gap between after 90s employees' situation and the after 90s graduates' expectation, we built the questions like "does the job achieve your expectation".

We distribute 180 questionnaires into three hotels with 60 questionnaires each. These three hotels are The Ritz-Carlton, The MGM and The Sheraton in Sanya which are all five star hotels. One week later we received 146 questionnaires with 43 questionnaires from The Ritz-Carlton, 48 
questionnaires from The MGM and 55 questionnaires from The Sheraton. In order to make the research more accurate and reflective, we corporate with the HR managers in these three hotels and held a morning meeting with the employees before we distributed the questionnaires. We introduced the objectives of the research and guaranteed their answers will be kept confidential. We tried to build the trust between the employees and us in order to make them relax and hope their answers can be more reflective.

In this questionnaire, we included 6 questions totally. The first question is "what is your current position" which can help us to know the percentage of managers in a hotel. Question number 3,4 and 5 which are "what is your motivation of work", "are you satisfied with your current job" and "does the job achieve your expectation" can help us gain a general understanding about the employees' job perception. And the last question "which part you do not like during the work” can help us find out the problems of the employees' work. After we get all these data, we can compare these data to the graduates' job expectation and find out what kind of gaps exists.

\subsubsection{Interviews}

The conversation which we had with the HR managers is using "question and answer" style. The contexts of the conversation are almost the same and we conclude three main questions and answers of the whole conversation. The questions include: "what kind of graduates is popular by employers"? "the impression and the comment of the graduates" and "the suggestion and advice of the HR managers give to graduates". we tried to find out the answers to the problems of the graduates and how they are expected to performed after they start to work.

\subsection{Data analysis}

In this article, we will use statistics as our main tool to analyze these data, calculate the percentage of each question and let it show us the answer, the trend, the problems and the phenomenon.

The table below gives us a summarize about the efficient amount of questionnaires we collected during the research:

Table. 1 Efficient amount of questionnaires

\begin{tabular}{|c|c|c|c|c|}
\hline & The Ritz-Carlton & The MGM & The Sheraton & Total \\
\hline $\begin{array}{c}\text { Questionnaires } \\
\text { (send) }\end{array}$ & 60 & 60 & 60 & 180 \\
\hline $\begin{array}{c}\text { Questionnaires } \\
\text { (back) }\end{array}$ & 43 & 48 & 55 & 146 \\
\hline $\begin{array}{c}\text { Efficient } \\
\text { questionnaires\% }\end{array}$ & $71.7 \%$ & $80 \%$ & $91.7 \%$ & $81.1 \%$ \\
\hline
\end{tabular}

\section{Results}

In this part, we are going to list three main results separately come from the school research, the hotel research, the interviews with HR managers.

\subsection{Results from the academy school research}

From the questionnaires we collected from Sanya university and Hainan Tropical Ocean University, we made a table below to show the questions and the answers: 
Table. 2 Students questionnaires (Sanya University and Hainan Tropical Ocean University) Data Form

\begin{tabular}{|c|c|c|c|}
\hline Questions & Options & Sanya University & $\begin{array}{l}\text { Hainan Tropical } \\
\text { Ocean University }\end{array}$ \\
\hline \multirow[t]{3}{*}{$\begin{array}{l}\text { What is your expect } \\
\text { position after you graduate }\end{array}$} & $\begin{array}{c}\text { Basic level leadership or } \\
\text { above }\end{array}$ & 46 & 42 \\
\hline & Basic level work & 28 & 30 \\
\hline & Obey the job assignment & 13 & 2 \\
\hline \multirow{4}{*}{$\begin{array}{c}\text { Why you choose tourism } \\
\text { and hospitality as your } \\
\text { main subject }\end{array}$} & I like it & 60 & 52 \\
\hline & Not think too much & 11 & 16 \\
\hline & It is not my choose & 9 & 4 \\
\hline & others & 7 & 2 \\
\hline \multirow[t]{4}{*}{ Your expected salary } & $0-4500 \mathrm{RMB}$ & 6 & 4 \\
\hline & 4500-5500RMB & 27 & 31 \\
\hline & 5500-6500RMB & 43 & 35 \\
\hline & Above 6500RMB & 11 & 4 \\
\hline \multirow[t]{4}{*}{$\begin{array}{l}\text { Why you refused a job } \\
\text { offer }\end{array}$} & $\begin{array}{l}\text { The salary and the welfare } \\
\text { benefit do not achieve my } \\
\text { expectation }\end{array}$ & 53 & 34 \\
\hline & $\begin{array}{l}\text { The hotel culture and } \\
\text { working atmosphere do not } \\
\text { achieve my expectation }\end{array}$ & 18 & 21 \\
\hline & Promotion space is limited & 11 & 9 \\
\hline & others & 5 & 10 \\
\hline \multirow[t]{4}{*}{$\begin{array}{c}\text { When you choose a job, } \\
\text { what is the first factor you } \\
\text { will consider }\end{array}$} & $\begin{array}{c}\text { The brand, } \\
\text { self-improvement and } \\
\text { self-promotion } \\
\end{array}$ & 29 & 21 \\
\hline & Salary and welfare benefit & 42 & 41 \\
\hline & location & 14 & 9 \\
\hline & others & 2 & 3 \\
\hline \multirow{3}{*}{$\begin{array}{l}\text { What factor make you be } \\
\text { refused by the employers } \\
\text { when you have interview }\end{array}$} & Work experience & 46 & 34 \\
\hline & High requests & 34 & 29 \\
\hline & others & 7 & 11 \\
\hline
\end{tabular}

From the result we get directly from the table above, we calculate some useful percentage as followed: 
Table. 3 Students questionnaires (Sanya University and Hainan Tropical Ocean University) percentage Form

\begin{tabular}{|c|c|c|c|}
\hline Questions & Options & $\begin{array}{l}\text { Two school together } \\
\text { (161) }\end{array}$ & $\%$ \\
\hline \multirow[t]{3}{*}{$\begin{array}{c}\text { What is your expect } \\
\text { position after you graduate }\end{array}$} & $\begin{array}{c}\text { Basic level leadership or } \\
\text { above }\end{array}$ & 88 & $54.7 \%$ \\
\hline & Basic level work & 58 & $36.0 \%$ \\
\hline & Obey the job assignment & 15 & $9.3 \%$ \\
\hline \multirow{4}{*}{$\begin{array}{c}\text { Why you choose tourism } \\
\text { and hospitality as your } \\
\text { main subject }\end{array}$} & I like it & 112 & $69.5 \%$ \\
\hline & Not think too much & 27 & $16.8 \%$ \\
\hline & It is not my choose & 13 & $8.1 \%$ \\
\hline & others & 9 & $5.6 \%$ \\
\hline \multirow[t]{4}{*}{ Your expected salary } & 0-4500RMB & 10 & $6.3 \%$ \\
\hline & 4500-5500RMB & 58 & $36.0 \%$ \\
\hline & 5500-6500RMB & 78 & $48.4 \%$ \\
\hline & Above 6500RMB & 15 & $9.3 \%$ \\
\hline \multirow[t]{4}{*}{$\begin{array}{l}\text { Why you refused the job } \\
\text { offer }\end{array}$} & $\begin{array}{l}\text { The salary and the welfare } \\
\text { benefit do not achieve my } \\
\text { expectation }\end{array}$ & 53 & $54.0 \%$ \\
\hline & $\begin{array}{l}\text { The hotel culture and } \\
\text { working atmosphere do not } \\
\text { achieve my expectation }\end{array}$ & 39 & $24.2 \%$ \\
\hline & Promotion space is limited & 20 & $12.5 \%$ \\
\hline & others & 15 & $9.3 \%$ \\
\hline \multirow[t]{4}{*}{$\begin{array}{c}\text { When you choose the job, } \\
\text { what is the first factor you } \\
\text { will consider }\end{array}$} & $\begin{array}{c}\text { The brand, } \\
\text { self-improvement and } \\
\text { self-promotion }\end{array}$ & 50 & $31.1 \%$ \\
\hline & Salary and welfare benefit & 83 & $51.6 \%$ \\
\hline & location & 23 & $14.2 \%$ \\
\hline & others & 5 & $3.1 \%$ \\
\hline \multirow{3}{*}{$\begin{array}{l}\text { What factor make you be } \\
\text { refused by the employers } \\
\text { when you have interview }\end{array}$} & Work experience & 80 & $49.7 \%$ \\
\hline & High requests & 63 & $39.1 \%$ \\
\hline & others & 18 & $11.2 \%$ \\
\hline
\end{tabular}

During this research, concerning their expectation position after graduation, most of the students have high expectation. $54.7 \%$ of the students want to achieve the basic level leadership or above directly and $93.7 \%$ of the students want their salary above 4500RMB after their graduation. But during the conversation we had with the managers in different hotels, they indicate normally they will just give the graduates some basic work after graduation; hotels seldom let them to become managers without familiar about the hotel and work experience. Even though some students have the internship experience during their $3^{\text {rd }}$ year, HR still need couple of month to inspect the performance of the graduate. Besides, different hotels have the different culture, therefore, graduates with internship experience still need time to adapt into the new environment. And according to the research, the average salary level in Sanya is 2500-3500 RMB which is much lower than the expectation of the graduates.

When we discussing about the reason why graduates refuse a job offer, $54.0 \%$ of the students refused the job is because they think the salary and the welfare benefit do not achieve my expectation, $24.2 \%$ of the students refused the job is because the hotel culture and working atmosphere do not achieve my expectation and $12.5 \%$ of the students refused the job is because the promotion space is limited in a hotel. And as we mentioned just now, 93.7\% of the students want their salary above 4500RMB, so that means most of the students can not achieve the consistency between their expectation and real salary offer in the life.

\subsection{Results from the hotel research:}

From the questionnaires we get back from the hotels, we list the data of the questionnaires as 
followed:

Table. 4 The employees questionnaire Data From

\begin{tabular}{|c|c|c|c|c|}
\hline Questions & Options & The Ritz-Carlton & The MGM & The Sheraton \\
\hline \multirow[t]{3}{*}{ Current position } & Basic level employees & 28 & 32 & 38 \\
\hline & $\begin{array}{c}\text { Basic level } \\
\text { management or above }\end{array}$ & 15 & 16 & 13 \\
\hline & others & 0 & 0 & 4 \\
\hline \multirow[t]{4}{*}{$\begin{array}{l}\text { Why you choose } \\
\text { hospitality industry }\end{array}$} & $\begin{array}{c}\text { Interest and career } \\
\text { planing }\end{array}$ & 21 & 19 & 26 \\
\hline & Live for life & 10 & 12 & 15 \\
\hline & Low entry request & 8 & 12 & 6 \\
\hline & others & 4 & 5 & 8 \\
\hline \multirow[t]{4}{*}{$\begin{array}{c}\text { What is your } \\
\text { motivation to work }\end{array}$} & $\begin{array}{c}\text { I love the job and have } \\
\text { my own career } \\
\text { planning }\end{array}$ & 13 & 14 & 19 \\
\hline & For salary and life & 20 & 23 & 27 \\
\hline & $\begin{array}{c}\text { No not have better } \\
\text { choice }\end{array}$ & 7 & 9 & 6 \\
\hline & others & 3 & 2 & 3 \\
\hline \multirow{4}{*}{$\begin{array}{c}\text { Are you satisfied } \\
\text { with your current } \\
\text { position }\end{array}$} & $\begin{array}{l}\text { Most of the time, yes, i } \\
\text { like it }\end{array}$ & 23 & 21 & 34 \\
\hline & Not too much & 6 & 7 & 7 \\
\hline & Just so so & 10 & 12 & 8 \\
\hline & others & 4 & 8 & 6 \\
\hline \multirow{4}{*}{$\begin{array}{l}\text { Is the job achieve } \\
\text { your expectancy } \\
\text { before you graduate }\end{array}$} & $\begin{array}{l}\text { Yes, that's exactly } \\
\text { what i want }\end{array}$ & 3 & 6 & 7 \\
\hline & Almost the same & 9 & 19 & 11 \\
\hline & So so & 22 & 17 & 28 \\
\hline & Not at all & 9 & 6 & 9 \\
\hline \multirow{4}{*}{$\begin{array}{l}\text { Which part until } \\
\text { now you are not } \\
\text { satisfactory }\end{array}$} & $\begin{array}{l}\text { I can not get } \\
\text { promotion fast. }\end{array}$ & 8 & 11 & 13 \\
\hline & $\begin{array}{c}\text { The salary in } \\
\text { hospitality industry is } \\
\text { still low }\end{array}$ & 21 & 26 & 23 \\
\hline & $\begin{array}{l}\text { I can not get very well } \\
\text { with the company } \\
\text { culture ,my boss or my } \\
\text { colleague }\end{array}$ & 11 & 8 & 15 \\
\hline & others & 3 & 3 & 4 \\
\hline
\end{tabular}

Among the result we get directly from the table above, we can conclude some useful percentage as followed: 
Table. 5 The employees questionnaire Percentage From

\begin{tabular}{|c|c|c|c|}
\hline Questions & Options & $\begin{array}{c}\text { Three hotels } \\
\text { together (146) }\end{array}$ & $\%$ \\
\hline \multirow[t]{3}{*}{ Current position } & Basic level employees & 98 & $67.1 \%$ \\
\hline & Basic level management or above & 44 & $30.1 \%$ \\
\hline & others & 4 & $2.8 \%$ \\
\hline \multirow{4}{*}{$\begin{array}{l}\text { Why you choose hospitality } \\
\text { industry }\end{array}$} & Interest and career planing & 66 & $45.2 \%$ \\
\hline & Live for life & 37 & $25.3 \%$ \\
\hline & Low entry request & 26 & $17.8 \%$ \\
\hline & others & 17 & $11.6 \%$ \\
\hline \multirow[t]{4}{*}{$\begin{array}{c}\text { What is your motivation to } \\
\text { work }\end{array}$} & $\begin{array}{c}\text { I love the job and have my own career } \\
\text { planning }\end{array}$ & 46 & $31.5 \%$ \\
\hline & For salary and life & 70 & $47.9 \%$ \\
\hline & No not have better choice & 22 & $15.1 \%$ \\
\hline & others & 8 & $5.5 \%$ \\
\hline \multirow{4}{*}{$\begin{array}{l}\text { Are you satisfied with your } \\
\text { current position }\end{array}$} & Most of the time, yes, i like it & 78 & $53.4 \%$ \\
\hline & Not too much & 20 & $13.7 \%$ \\
\hline & Just so so & 30 & $20.5 \%$ \\
\hline & others & 18 & $12.3 \%$ \\
\hline \multirow{4}{*}{$\begin{array}{l}\text { Is the job achieve your } \\
\text { expectancy before you } \\
\text { graduate }\end{array}$} & Yes, that's exactly what i want & 16 & $11 \%$ \\
\hline & Almost the same & 39 & $26.7 \%$ \\
\hline & So so & 67 & $45.9 \%$ \\
\hline & Not at all & 24 & $16.4 \%$ \\
\hline \multirow{4}{*}{$\begin{array}{l}\text { Which part until now you } \\
\text { are not satisfactory }\end{array}$} & I cannot get promotion fast. & 32 & $21.9 \%$ \\
\hline & $\begin{array}{c}\text { The salary in hospitality industry is still } \\
\text { low }\end{array}$ & 70 & $47.9 \%$ \\
\hline & $\begin{array}{l}\text { I cannot get very well with the company } \\
\text { culture ,my boss or my colleague }\end{array}$ & 34 & $23.4 \%$ \\
\hline & others & 10 & $6.8 \%$ \\
\hline
\end{tabular}

During this research, we know that $30.1 \%$ of the staff is basic level management or above and $67.1 \%$ are the basic level employees, that shows us in hotels, only small part of people can achieve management level, so the graduates should clearly know that it is not easy to achieve management level especially when you just graduated. Therefore, the graduates should have the preparation to work hard on the basic level before getting promoted.

According to the data, only $45.2 \%$ of the staff are really interested with their job and have the career planning when they choose the hotel industry and $43.1 \%$ of the staff do the job just because low entry request or just work for life. In addition, the motivation data told us $47.9 \%$ of the staff just come work for life or salary. So this may be the reason causing the staff to lack passion from heart to work and that will affect the service qualification and customer satisfaction.

So when we research bout the expectation achievement question, $11 \%$ staff think this is the job exactly what they want, $26.7 \%$ of the staff think it is almost the same as they expected before, but there are still more than $50 \%$ people think this is just so or it is not what they want. Therefore, when we research further about why the job did not achieve their expectation and what part of the job they do not like, salary with $47.9 \%$ is still the point most people not satisfactory, and then is the "I cannot get very well with the company culture, my boss or my colleague" with $23.4 \%$ and promotion in the third place with $21.9 \%$.

\subsection{Results from the interview with hotel managers:}

After the quantity data we listed above, we can also have some useful quality information form the interview we didi with the hotel HR managers.

Conclude the three questions and answers fro the interviews we did with hotel managers, the table can be draw as followed: 
Table. 6 Questions and answers of the hotels

\begin{tabular}{|c|c|c|}
\hline $\begin{array}{c}\text { What kind of gradates now is } \\
\text { popular by hotels }\end{array}$ & The Ritz-Carlton & The MGM \\
\hline $\begin{array}{c}\text { W/ work experience } \\
\text { High degree } \\
\text { Good teamwork } \\
\text { Work hard } \\
\text { Good attitude }\end{array}$ & $\begin{array}{c}\text { W/ work experience } \\
\text { Team work spirit } \\
\text { Communication skills } \\
\text { The impression and the } \\
\text { comment on the graduates }\end{array}$ & $\begin{array}{c}\text { English } \\
\text { Work hard } \\
\text { Good attitude }\end{array}$ \\
$\begin{array}{c}\text { Some have attitude problems } \\
\text { Lack of management skills }\end{array}$ & $\begin{array}{c}\text { Most of them are good } \\
\text { Attitude problems } \\
\text { Do not understand the social } \\
\text { situation }\end{array}$ \\
\hline $\begin{array}{c}\text { The suggestions and advice to } \\
\text { the graduates }\end{array}$ & Clear understanding & Right cognition and expectation \\
\hline
\end{tabular}

The first question is about what kind of graduates is on need now, generally speaking, the graduates who have the work experience, with good attitude and teamwork spirit are the people demanded by the hotels. And as we talk about the problems of the graduates. The two hotels are showing almost the some problems. Both of these hotels consider that there is an attitude problem among some graduates. During the conversation, managers show that the graduates do bot have a right identification about the hospitality industry and their hob, so they did not show the passion about the job when they really do it.

\section{Discussion}

The result from the interview we had with hotel managers can help us achieve the first research objective which is try and find out what kind of graduates in on needed, namely the market need.

Both of the managers indicate that graduates who has the work experience are much more popular, so that means it will be much easier to find a job if the graduates have some internship pr practice experience before they graduate. According to the research, even though all the graduates have the half-year internship during their $3^{\text {rd }}$ year, they are still requested to work at the basic level position if their job intention is different from the position they worked during the internship. The good news is if their job intention is still the department they did during their internship, it will increase the possibility to get the position such as supervisor or so directly.

Attitude is another factor mentioned by a lot during the interviews. Managers consider negative work attitude as one of the reason that cause low quality service and customer complains. And they think the incorrect conception about hospitality industry is the main reason causing the attitude problem. Besides when we asked which part until now you are not satisfactory, "I cannot get very well with the company culture, my boss or my colleague" occupied $23.4 \%$. The most obvious character of after 90s is their growing up self-awareness. They start to concern more about the self-feeling, self-emotion, self-promotion and self-life quality. That means hotels need to change the traditional management method while dealing with the after 90s.

The results from the questionnaires we had from the academy schools and the employees can help us achieve the second and the third research objective which are try to find a general understanding about the graduates and the job satisfaction degree of the employees. We try to find out the gap through comparing what the graduates expect when they are still in school and what employees will really have when they started work.

We know that more than $50 \%$ of the graduates want to achieve the basic management level or above directly after they graduates according to our research, but as we showed before, usually the percentage of management employers in a hotel is $30.1 \%$. so that means there are a lot of graduates that cannot achieve the position they want. In addition, because the graduates do not familiar with the business of the hotel, it is really hard for them to be a manager directly without starting from the basic level.

93.7\% graduates want their salary above 4500RMB and at the same time the average salary for 
the first job offer is 2500-3500RMB. With the development of society, the commodity price, house price and the cost of living are all increasing, but the salary of hospitality industry, especially the salary of basic level employer is still low. Graduates need to have the clear cognition about the character of hospitality industry.

\section{Conclusion}

If the hotel industry wants to be competitive in the world, it needs to achieve a $100 \%$ customer satisfaction and also need to have excellent employees' and managers, so the hotels need to recruit capable graduates.

Focus on the human resources shortage problems, the aim of this research is to find out the gaps between graduates' expectation and the markets' need through questionnaires and conversations

Questionnaires and interview are the man tools we are using in this research; we choose three five star hotels and two academy schools as our target to go through this research. Questionnaires are mainly used to get the quantity data and interviews are mainly used to get the quality information.

After we go through all the research objectives and the data discussion, we found lack of right cognition about hospitality industry is the main reasons which causing the gap among the graduates. Besides, because of the different character and personality of after 90s, hotels need to change their management method while dealing with the after 90 s.

\section{Acknowledgements}

During the whole process of writing, I need to appreciate manager Qin \&manager Li who arranged the interview for me to help gain useful information which is used for the dissertation; also I need to appreciate Bruno Eeckels who give the guidance of this research.

\section{References}

[1] Barron, P.E. (2004). An evaluation of learning styles, learning issues and learning problems of Confucian heritage culture students studying hospitality and tourism management in Australia. Unpublished PhD Thesis. The University of Queensland, Brisbane, Australia.

[2] Honey, P. and Mumford, A.(2000). The Learning Styles Questionnaire: 80 Items Version. Maidenhead, Berkshire UK, Peter Honey Publication Ltd.

[3] Han Jia (2005). Needs and Concerns of International Students: What Can Educators Do? Hospitality and Tourism Educator 8, 2/3, 68-75.

[4] Xiang Su, Dawei Wang, Leilei Hao, Wenting Li, Xiuqing Qiao. (2015). The Effect of Transformational Leadership on Employee' s Work Adjustment of the New Generation After 90s:The Mediating Effect of Work Values. Proceedings of 2015 SSR International Conference on Social Sciences and Information(SSR-SSI 2015 V10).

[5] Song Ying, LI Yongzhou. (2017). Research on the Relationship between Organizational Embeddedness and Job Performance among the Generation after 90s-—Self Efficacy as Mediating Variable. The 2nd International Conference on Politics, Economics and Law(ICPEL 2017). 